\title{
PREVALENCE OF INTESTINAL PARASITISM AND ASSOCIATED SYMPTOMATOLOGY AMONG HEMODIALYSIS PATIENTS
}

Frederico F. GIL(1), Maxlene J. BARROS(2), Nazaré A. MACEDO(2), Carmelino G.E. JÚNIOR(2), Roseli REDOAN(2), Haendel BUSATTI(1), Maria A. GOMES(1) \& Joseph F.G. SANTOS(2)

\begin{abstract}
SUMMARY
Intestinal parasites are an important cause of morbidity and mortality. Immunocompromised individuals may develop more severe forms of these infections. Taking into account the immunity impairment in patients suffering from chronic renal failure (CRF), we will determine the prevalence and associated symptoms of intestinal parasites in these patients. Controls without CRF were used for comparison. Stool samples were collected and processed for microscopic identification of parasites using the Formalin-ether concentration method. For Cryptosporidium diagnosis, the ELISA technique was used. One hundred and ten fecal samples from hemodialysis patients were analyzed, as well as 86 from a community group used as control group. A result of 51.6\% of intestinal parasites was observed in hemodialysis patients and $61.6 \%$ in the control group. Cryptosporidium and Blastocystis were the most common infections in patients with CRF (26.4\% and 24.5\%, respectively). Blastocystis was the most common infection in the control group (41.9\%), however no individual was found positive for Cryptosporidium. Among the CRF patients, $73.6 \%$ were symptomatic, $54.3 \%$ of these tested positive for at least one parasite, in contrast to $44.8 \%$ in asymptomatic patients $(p=0.38)$. The most common symptoms in this group were flatulence (36.4\%), asthenia $(30.0 \%)$ and weight loss $(30.0 \%)$. In the control group, $91.9 \%$ were symptomatic, $60.8 \%$ of these tested positive for at least one parasite, in contrast to $71.4 \%$ in asymptomatic patients $(p=0.703)$. A significant difference between the two groups was observed with regard to symptoms, with bloating, postprandial fullness, and abdominal pain being more frequent in the control group than in the hemodialysis group (all $p<0.05$ ). Comparing symptomatic with asymptomatic, there was no association in either group between symptoms or the prevalence of parasitic infection, nor with the type of parasite or with multiple parasitic infections. Patients with chronic renal failure are frequent targets for renal transplantation, which as well as the inherent immunological impairment of the disease itself, results in immunosuppression by medication. For this reason, carriers of intestinal parasites with pathogenic potential can develop serious clinical complications influencing the success of transplantation. This fact, coupled with the high prevalence of intestinal parasites and the dissociation between symptoms and infection in CRF patients, suggests that the stool test should be incorporated in routine propedeutics. Furthermore, preventive measures for the acquisition of parasites through the fecal-oral contamination route should be introduced.
\end{abstract}

KEYWORDS: Enteroparasitosis; Hemodialysis patients; Symptoms.

\section{INTRODUCTION}

Intestinal parasitosis constitutes a major public health problem, especially in developing countries, where inadequate sanitary conditions and lack of information result in the contamination of food and water sources, with a consequent perpetuation of parasite cycles. However, even in countries where adequate sanitation conditions and education predominate, some of these parasites play an important role in triggering diseases in specific groups such as immunocompromised individuals and young children ${ }^{10}$. Within the immunocompromised group are patients suffering from terminal chronic renal disease, which once established causes progressive and irreversible loss of kidney function leading to the need for renal replacement therapy ${ }^{16,22}$. Patients with chronic renal failure (CRF) undergoing hemodialysis are individuals whose immune system is significantly compromised. Among the changes related to immunodepression detected in these patients, we can cite the presence of uremic toxins which mainly impair the granulocytic but also the lymphocytic function ${ }^{3,4,9,14,21,23}$; malnutrition, present in a large number of patients ${ }^{35}$; vitamin deficiencies, resulting either from inadequate intake, or from losses during dialysis procedures ${ }^{9,14,23}$; blood exposure to artificial membranes with the inflammatory activation and release of cytokines, causing the activation of monocytes and the complement cascade that lead to a change in the immune response against infectious agents $^{28}$, changes in the coagulation cascade; frequent and repeated 


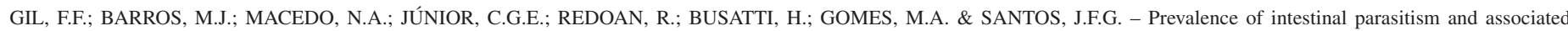
symptomatology among hemodialysis patients. Rev. Inst. Med. Trop. Sao Paulo, 55(2): 69-74, 2013.

episodes of per-dialysis hypotension, with the activation of leukocytes, lymphocytes, and nitric oxide; platelet dysfunction and anemia causing specific immunological changes ${ }^{5,11,12,31}$; breaking of the cutaneous immune barrier and that of the mucosal surfaces, mainly due to functional changes in the surface of immunoglobulins, neutrophils, platelets, and the coagulation cascade $9,14,17,30$.

Due to a condition of such severe immunity impairment, studies have shown that patients suffering from chronic renal failure demonstrate an increased susceptibility to infections in general, but mainly to bacterial infections in the respiratory, digestive and urinary systems and in the skin. Such infections are responsible for somewhere between 14-40\% of the deaths of these patients ${ }^{13,18,30}$.

Intestinal parasitosis, especially that caused by Cryptosporidium spp and Blastocystis hominis, has also been reported as a clinically important infection not only in immunocompromised patients but also in hemodialysis and renal transplant patients, with the prevalence data in these groups ranging from $15-25 \%$ and $20-35 \%$ respectively ${ }^{2,8,24,31,34}$. Such infections can cause uremic symptoms in patients to be aggravated, which as well as compromising their quality of life play an important role in the progress of those patients who will undergo kidney transplants.

Gastrointestinal symptoms are very common in patients with CRF on dialysis, especially hyporexia, diarrhea (chronic or acute), nausea, vomiting, and abdominal pain ${ }^{16,22}$. In most cases, chronic uremia may explain the occurrence of these symptoms. Chronic uremia however, may be an indication of other diseases such as intestinal parasitosis which exhibits similar symptoms, and the two conditions may therefore overlap. The investigation of parasitic infections in these patients, followed by any necessary treatment if tested positive, can therefore play an important role in the process of restoring the patients' quality of life.

The present study determines the prevalence and symptoms associated with enteroparasitosis in CRF patients of the Dialysis Center of the Hospital Nossa Senhora das Graças, in Sete Lagoas, Minas Gerais, Brazil.

\section{MATERIAL AND METHODS}

This was a cross-sectional study, in which all hemodialysis patients were included who signed the consent form and completed the clinical standardized questionnaire containing data regarding the symptoms classically associated with intestinal parasitosis. The individuals in this group belong predominantly to low income households and are cared for by the public health system of Brazil (the Unified Health System - Ministry of Health). Three stool samples of each participant were collected on alternate days and stored in buffered formalin $10 \%$. The fecal material was concentrated for microscopic identification of parasites using the Formalin-ether concentration method ${ }^{36}$. The morphological identification of Entamoeba histolytica was carried out in the laboratory of amoebiasis at the Federal University of Minas Gerais, which is considered a leading institution in the morphological and molecular diagnosis of this parasite. For diagnosing Cryptosporidium, the ELISA technique was used to identify coproantigens (Cryptosporidium II Test, Wampole ${ }^{\circledR}$ ).

For comparison, fecal samples were collected from adults over 18 years of age who did not suffer from any kidney problems, all from the Santa Maria community in Belo Horizonte which is comprised predominantly of low income families. Written consent was obtained from all study participants. These samples were processed in a similar way to those of hemodialysis patients. The same standardized clinical questionnaire was also applied.

This study was approved by the Ethical Review Committee of the Municipality Health Service of Belo Horizonte protocol number 027/2007.

Data were presented as mean \pm standard deviation or median with the interquartile range or as percentages and proportions. For the categorical variables, the chi-square or Fisher exact test was used and the t-Student or U-Mann-Whitney test was used for the continuous variables as appropriate. Differences with a $p$ lower than 0.05 were considered statistically significant.

\section{RESULTS}

Feces were collected from a total of 110 dialysis patients with a mean age of $52.8 \pm 14.8$ years, $50.9 \%$ of them male. Twenty-eight patients $(25.5 \%)$ were elderly patients aged 65 or older. Out of the 110 samples, $57(51.8 \%)$ tested positive for intestinal parasites, among them: Cryptosporidium, 29 (26.4\%); Blastocystis hominis, 27 (24.5\%); Endolimax nana, 22 (20.0\%); Entamoeba coli, 7 (6.4\%); E. histolyticalE. dispar, 4 (3.6\%); Giardia lamblia, 1 (0.9\%); Strongyloides stercoralis, 1 $(0.9 \%)$ (Table 1$)$. Polyparasitism was present in $38.6 \%$ of dialysis patients.

Table 1

Prevalence of enteroparasites in hemodialysis patients and control group

\begin{tabular}{lccccc}
\hline \multirow{2}{*}{ Parasites } & \multicolumn{2}{c}{$\begin{array}{c}\text { Hemodialysis } \\
\text { patients }\end{array}$} & \multicolumn{2}{c}{ Control group } & \multirow{2}{*}{$p$} \\
\cline { 2 - 5 } & $\mathrm{N}$ & $\%$ & $\mathrm{~N}$ & $\%$ & \\
\hline Cryptosporidium $*$ & 29 & 26.4 & 0 & 0.0 & $<0.0001$ \\
Blastocystis hominis $*$ & 27 & 24.5 & 36 & 41.9 & 0.010 \\
Endolimax nana & 22 & 20.0 & 17 & 19.8 & 0.968 \\
Entamoeba coli* & 7 & 6.4 & 15 & 17.4 & 0.015 \\
E. histolytica/E. dispar & 4 & 3.6 & 4 & 4.7 & 0.732 \\
Strongyloides stercoralis & 1 & 0.9 & 0 & 0.0 & 1.000 \\
Giardia lamblia & 1 & 0.9 & 2 & 2.3 & $0.583 *$ \\
\hline
\end{tabular}

$*(p<0.05)$

Among the dialysis patients, 81 (73.6\%) were symptomatic, $54.3 \%$ tested positive for some parasite in the stool test in contrast to $44.8 \%$ of asymptomatic individuals $(\mathrm{OR}=1.464-\mathrm{CI}=0.624$ to 3.433 and $p$ $=0.38)$. The most frequent symptoms among them were: flatulence, $40(36.4 \%)$; adynamia, 33 (30.0\%); weight loss, 33 (30.0\%); bloating, $29(26.4 \%)$; increased abdomen, $25(22.7 \%)$; nausea or vomiting, 23 (20.9\%); postprandial fullness, 21 (19.1\%); abdominal pain, $19(17.3 \%)$; diarrhea, 12 (10.9\%) (Table 3).

In the control group, 86 stool samples were collected from healthy adult individuals without kidney disease, who had a mean age of 41.5 


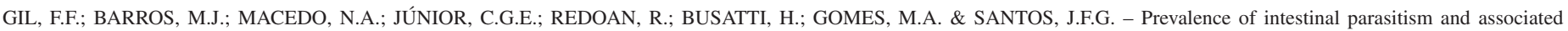
symptomatology among hemodialysis patients. Rev. Inst. Med. Trop. Sao Paulo, 55(2): 69-74, 2013.

\pm 14.4 years, $57(66.3 \%)$ of them male. Eight individuals $(9.3 \%)$ were elderly patients aged 65 or older. Fifty-three samples $(61.6 \%)$ were positive for intestinal parasites, with the following prevalence: Blastocystis hominis, 36 (41.9\%); Endolimax nana, 17 (19.8\%); Entamoeba coli, 15 (17.4\%); E. histolyticaldispar, 4 (4.7\%); Giardia lamblia, 2 (2.3\%) (Table 1). Polyparasitism was present in $32.1 \%$ of control patients.

Among the control patients, 79 (91.9\%) were symptomatic, $60.8 \%$ of whom tested positive for some parasite in the stool test, in contrast to $71.4 \%$ of asymptomatic individuals $(\mathrm{OR}=0.6-\mathrm{CI}=0.11-3.39$ and $p$ $=0.703)$. The most frequent symptoms in this group were: postprandial fullness, 47 (54.7\%); flatulence, 46 (53.5\%); and abdominal pain, 36 (41.9\%) (Table 2).

When comparing the prevalence of parasites in both groups (Table 1), we found that Cryptosporidium was present only in the group of dialysis

Table 2

Identified symptoms in hemodialysis patients and control group

\begin{tabular}{lccccc}
\hline \multirow{2}{*}{ Symptoms } & \multicolumn{2}{c}{$\begin{array}{c}\text { Hemodialysis } \\
\text { patients }\end{array}$} & \multicolumn{2}{c}{ Control group } & \multirow{2}{*}{$p$} \\
\cline { 2 - 5 } & $\mathrm{N}$ & $\%$ & $\mathrm{~N}$ & $\%$ & \\
\hline Flatulence* & 40 & 36.4 & 46 & 53.5 & 0.008 \\
Adynamia & 33 & 30.0 & 34 & 39.5 & 0.163 \\
Weight loss & 33 & 30.0 & 18 & 22.0 & 0.212 \\
Bloating* & 29 & 26.4 & 0 & 0 & $<0.0001$ \\
Increased abdomen & 25 & 22.7 & 27 & 31.8 & 0.157 \\
Nausea or vomiting & 23 & 20.9 & 13 & 15.1 & 0.299 \\
Postprandial fullness* & 21 & 19.1 & 47 & 54.7 & $<0.0001$ \\
Abdominal pain* & 19 & 17.3 & 36 & 41.9 & $<0.0001$ \\
Diarrhea & 12 & 10.9 & 17 & 19.8 & 0.050 \\
\hline
\end{tabular}

$*(p<0.05)$ patients $(p<0.0001)$, and that the Blastocystis hominis and Entamoeba coli were significantly more prevalent in the control group $(p<0.05)$.

As for reported symptoms (Table 2), there was a significant difference between the two groups: flatulence, postprandial fullness and abdominal pain were more prevalent in the control group than in hemodialysis patients (all $p<0.05$ ), but bloating showed up only in dialysis patients $(p<0.05)$.

However, when comparing the symptomatic and asymptomatic patients, no significant differences were detected in the prevalence of various parasites in both groups under study (Table 3).

When the symptoms in each group and the association with symptoms of infection by each parasite were assessed separately, no association was found. There was also no association with symptoms of polyparasitism. There was also no difference between hemodialysis patients and the control group regarding the ratio of patients with polyparasitism (38.6 X $32.1-p=0.475$ ).

There were significant differences between the two groups with regard to age $(52.8 \pm 14.8$ years - dialysis patients $X 41.5 \pm 14.4$ years - control group $-p<0.0001$ ), in the sex ratio (male $-50.9 \%$ in dialysis patients $\mathrm{X} 66.3 \%$ in the control group $-p=0.031$ ), and in the ratio of elderly people $(25.5 \%$ in dialysis patients $X 9.3 \%$ in the control group). However, there was no correlation among age and sex with either symptoms, general and specific, or with infection, overall or by specific parasites.

Analyzing diabetic patients (data available only for hemodialysis group), of which 27 (24.5\%) were diabetic patients, and $83(75.5 \%)$ nondiabetic, we found no difference in the prevalence of intestinal parasitosis $(37.0 \%$ for diabetic patients versus $56.6 \%$ in nondiabetic patients $-p=0.120$ ), nor in the symptoms between the diabetic and those without diabetes $(77.8 \%$ X $72.3 \%-p=0.626)$, including each specific parasitosis or symptom.

Among the hemodialysis patients, $51 \%$ were suitable for renal transplantation, and $47.3 \%$ of them tested positive for some parasite

Table 3

Relationship between parasite prevalence and symptoms in hemodialysis patients and in control group

\begin{tabular}{|c|c|c|c|c|c|c|c|c|c|c|}
\hline \multirow{3}{*}{ Parasites } & \multicolumn{5}{|c|}{ Hemodialysis patients } & \multicolumn{5}{|c|}{ Control group } \\
\hline & \multicolumn{2}{|c|}{ Symptomatic } & \multicolumn{2}{|c|}{ Asymptomatic } & \multirow[b]{2}{*}{$p$} & \multicolumn{2}{|c|}{ Symptomatic } & \multicolumn{2}{|c|}{ Asymptomatic } & \multirow{2}{*}{$p$} \\
\hline & $\mathrm{N}$ & $\%$ & $\mathrm{~N}$ & $\%$ & & $\mathrm{~N}$ & $\%$ & $\mathrm{~N}$ & $\%$ & \\
\hline Cryptosporidium & 23 & 28.4 & 6 & 20.7 & 0.419 & - & - & - & - & - \\
\hline Blastocystis hominis & 20 & 24.7 & 7 & 24.1 & 0.953 & 32 & 40.5 & 4 & 57.1 & 0.446 \\
\hline Endolimax nana & 14 & 17.3 & 8 & 27.6 & 0.234 & 17 & 21.5 & 0 & 0.0 & 0.336 \\
\hline Entamoeba coli & 5 & 6.2 & 2 & 6.9 & 1.000 & 13 & 16.5 & 2 & 28.6 & 0.600 \\
\hline E. histolytica/E.dispar & 3 & 3.7 & 1 & 3.4 & 1.000 & 2 & 2.5 & 2 & 28.6 & 0.072 \\
\hline Strongyloides stercoralis & 1 & 1.2 & 0 & 0.0 & 1.000 & 1 & 1.2 & 0 & 0.0 & 1.000 \\
\hline Giardia lamblia & 1 & 1.2 & 0 & 0.0 & 1.000 & 2 & 2.5 & 0 & 0.0 & 1.000 \\
\hline Trichuris trichiura & - & - & 1 & 0.8 & 1.000 & 1 & 0.9 & 0 & 0.0 & 1.000 \\
\hline
\end{tabular}




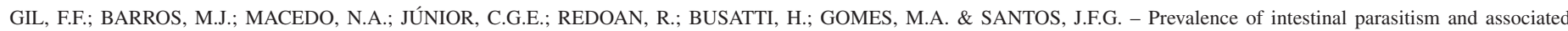
symptomatology among hemodialysis patients. Rev. Inst. Med. Trop. Sao Paulo, 55(2): 69-74, 2013.

in the stool test. The two most frequent parasites were B. hominis, 14 (27.5\%) and Cryptosporidium, 11 (21.6\%).

\section{DISCUSSION}

Studies determining the prevalence of enteroparasitosis in CRF patients on dialysis are scarce and have shown high infection rates, mainly by protozoa ${ }^{2,8,24,31,34}$. The impact of this parasitosis on the health of immunocompetent individuals is already known, and there may be impairment of the nutritional and immune condition culminating in an increased risk of bacterial, viral, and fungal co-infections ${ }^{35}$. Lower socioeconomic groups are associated with poor sanitation, inadequate hygiene habits, consumption of untreated water and malnutrition, leading to the onset of enteroparasitosis.

In the present study there was a high prevalence of parasitosis in both healthy subjects and hemodialysis patients $(51.3 \%$ and $61.6 \%$ respectively), however there was no significant difference among them. Although both groups belong to a low income population, they live in communities with sewage systems and clean water, and lower prevalence rates would therefore be expected. It is possible that these groups have other sources of contamination and perpetuation of parasite cycles, which may include sources of contaminated food, poor information and a behavior pattern that favors contamination by enteroparasites.

Studies determining the prevalence of enteroparasites in chronic renal failure patients have shown rates ranging from $11 \%$ to $34 \%$ 2,8,34. A study comparing 86 patients on hemodialysis and 146 healthy individuals found significant differences in the prevalence of enteroparasites between both groups $(45.1 \% \times 26.7 \%-p=0.0318)$, and a greater ratio of polyparasitism in patients on dialysis $(9.2 \% \text { vs. } 0.9 \%-p=0.0019)^{19}$. In the present study, the high ratios of polyparasitism did not differ in these two groups (38.6 X $32.1-p=0.475)$. Regional variations and socioeconomic characteristics between the two studies could explain such differences. In the present study, controls with similar socioeconomic characteristics to those of dialysis patients were included, such as individuals with a low level of education, an average family income of US $\$ 400.00$, living in a population density of around $18,000.00$ inhab/km2 and with water provided by the same water and sewage treatment company.

Diabetes mellitus is now the second largest cause of chronic renal disease. It leads to the simultaneous impairment of other organs also affecting the immune system. In this study, Diabetes mellitus was present in $24.5 \%$ of the hemodialysis group, while no data was available for the control group. However, a few studies have assessed the prevalence of intestinal parasitosis in this group. SEYRAFIAN et $a l$. (2006) found a significant difference between the groups (diabetic $\mathrm{x}$ nondiabetic patients) regarding the prevalence of Cryptosporidium ( $19.4 \%$ vs. $8.3 \%$, respectively $-p<0.05$ ), but not in the occurrence of associated symptoms ${ }^{32}$. NAZLIGUL et al. (2001) found a significantly lower prevalence in diabetic patients than in the control subject group (47 vs. 55\%, $p, 0.05)^{25}$. ABAZA et al. (1995) designed a study to find out the prevalence of different intestinal opportunistic parasites in different groups of immunocompromised hosts, including diabetic and renal failure patients, with an $8 \%$ and $28.8 \%$ prevalence of intestinal parasitosis respectively ${ }^{1}$. BAIOMY et al. (2010) found the prevalence of intestinal parasitosis in $6 \%$ of both diabetic and renal failure patients, which was less than for patients suffering from malignancy $(18 \%)^{6}$.
We found no difference in the prevalence of any parasites among diabetic and nondiabetic patients, and a comparison of these two groups showed no association between Diabetes mellitus and the symptoms. However, there is a lack of studies that have adequately assessed the symptoms of intestinal parasitosis in this group of patients.

Although there was a significant difference among the mean age, the sex ratio, and the number of elderly subjects between the two groups in the study, these variables were not associated with either the symptoms or with the prevalence of parasites. It is known that hemodialysis patients constitute a group of patients who are increasingly older, because at present it is a chronic renal disease resulting mainly from diseases such as Diabetes mellitus and systemic hypertension, which will most often lead the patient to the final stage of renal disease in later life. With regard to sex, it is possible that there were a greater number of males within the community.

Considering the symptoms and their association with parasitism, there was no association relating them to the presence of any parasites even when comparing symptomatic and asymptomatic patients in both groups. The presence of chronic uremia may mask some symptoms associated with intestinal parasitosis since some of the most frequent symptoms in patients suffering from both conditions are nausea, vomiting, and abdominal pain. It is therefore possible to misdiagnose enteroparasitosis which will cause the physician to overlook these symptoms. It may therefore be the case that certain symptoms reported by patients on dialysis were underestimated.

Our results are corroborated by studies which have been done on the prevalence of intestinal parasitosis in hemodialysis patients, especially when assessing the presence of Cryptosporidium and Blastocystis in these populations ${ }^{2,8,24,31,34}$. Cryptosporidium, B. hominis and Endolimax nana were the most frequent parasites in the hemodialysis group. Except for Cryptosporidium which was not found in the control group, the other two protozoa were found to be significant, and B. hominis prevailed. Such a result reinforces the theory of immunodeficiency as a determinant for Cryptosporidium infections.

Opportunistic diseases are closely related to immunodeficiency conditions ${ }^{2}$. Cryptosporidium is responsible for ephemeral and asymptomatic infections in the most immunocompetent individuals. Symptomatic and long-lasting infections are frequent in immunocompromised subjects ${ }^{10,34}$.

Blastocystis was the most common infection in the control group, and the second most frequent in the hemodialysis group after Cryptosporidium. This protozoan is among one of the most common organisms to be detected in stool specimens, but there has been considerable controversy regarding whether they represent a commensal organism or a true pathogen. The mode of transmission is not fully understood; fecal-oral transmission has been postulated ${ }^{7}$. Some authors have suggested that contaminated water may also be a source of infection ${ }^{15,20}$. Blastocystis spp have also been found in animals including pigs, monkeys, rodents and poultry. There seems to be poor host specificity; transmission occurs from human to human and between humans and animals ${ }^{29}$.

The prevalence varies between countries and between communities ${ }^{26,27,33}$. In general, the estimated prevalence of Blastocystis is higher in developing countries than in developed ones (30 to 50 


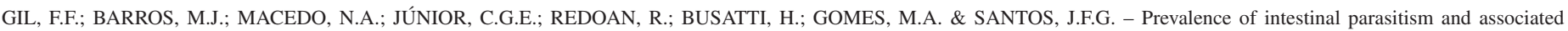
symptomatology among hemodialysis patients. Rev. Inst. Med. Trop. Sao Paulo, 55(2): 69-74, 2013.

percent and 5 to 10 percent respectively). There are fewer studies in hemodialysis patients assessing the prevalence of this organism. KULIK et al. ${ }^{19}$, who studied 86 hemodialysis patients and 145 healthy controls, found a Blastocystis prevalence of $20.9 \%$ and zero respectively, the most prevalent protozoan being in the first group.

Hemodialysis patients may be admitted at any time for a renal transplant and consequently to medicamental immunosuppression. In this case, carriers of enteroparasites with pathogenic potential may undergo significant clinical complications influencing the success of a transplant $2,8,24,34$. Considering the above and the high prevalence of parasitic infections found in patients on hemodialysis, the stool test should be incorporated into the routine propedeutics of these patients, coupled with preventive measures for the acquisition of parasites through the fecal-oral contamination route.

\section{RESUMO}

\section{Prevalência de parasitismo intestinal e sintomatologia associada em pacientes hemodialíticos}

Doenças parasitárias infectam grande número de indivíduos em todo o mundo. Manifestações clínicas mais severas podem se apresentar em pacientes imunocomprometidos. Considerando o importante comprometimento imunológico observado em pacientes com insuficiência renal crônica (IRC), foi determinada a prevalência e sintomas associados a parasitoses intestinais nesses pacientes em comparação a controles saudáveis. Foram coletadas amostras fecais de cada participante e processadas para identificação microscópica dos parasitas pelo método de concentração por formol-éter. Foi utilizada a técnica de ELISA para identificar coproantígenos de Cryptosporidium. Foram analisadas 110 amostras fecais de pacientes em hemodiálise e 86 de um grupo controle comunitário. Cryptosporidium e Blastocystis foram as infecções mais freqüentes nos pacientes em hemodiálise $(26,4 \%$ e $24,5 \%$, respectivamente). Blastocystis foi a infecção mais freqüente no grupo controle $(41,9 \%)$, entretanto nenhum indivíduo positivo para Cryptosporidium foi identificado. Considerando os pacientes com IRC, $73,6 \%$ eram sintomáticos, sendo $54,3 \%$ positivos para algum parasita, contra $44,8 \%$ nos assintomáticos $(p=0,38)$. Os sintomas mais frequentes neste grupo foram flatulência $(36,4 \%)$, adinamia $(30,0 \%)$ e perda de peso $(30,0 \%)$. No grupo controle, $91,9 \%$ eram sintomáticos, sendo $60,8 \%$ positivos para algum parasita, contra $71,4 \%$ nos assintomáticos $(\mathrm{p}=0,703)$. Em relação aos sintomas, houve diferença significativa entre os dois grupos, sendo que flatulência, plenitude pós-prandial, e dor abdominal foram mais freqüentes no grupo controle que nos pacientes em hemodiálise (todos $p<0,05$ ). Comparando-se sintomáticos com assintomáticos, não houve associação entre a sintomatologia e a prevalência de parasitose, nem com o tipo de parasita, e nem com o poliparasitismo, nos dois grupos. Considerando que pacientes com IRC são frequentes alvos de transplante renal, resultando em imunossupressão por medicamentos, que é somada à deficiência imunológica inerente à própria doença. Os portadores de parasitas intestinais com potencial patogênico podem desenvolver sérias complicações clínicas que influenciam o sucesso do transplante. Este fato, aliado a alta prevalência de parasitas intestinais e dissociação entre os sintomas e infecção nesses pacientes, sugerem a incorporação do exame de fezes na propedêutica de rotina dos mesmos, juntamente com medidas preventivas para a aquisição de parasitas com rota de contaminação fecal-oral.

\section{ACKNOWLEDGMENTS}

This work was supported by Pró-Reitoria de Extensão - UFMG by granting scholarships.

\section{REFERENCES}

1. Abaza SM, Makhlouf LM, el-Shewy KA, el-Moamly AA. Intestinal opportunistic parasites among different groups of immunocompromised hosts. J Egypt Soc Parasitol. 1995;25:713-27.

2. Ali MS, Mahmoud LA, Abaza BE, Ramadan MA. Intestinal spore-forming protozoa among patients suffering from renal failure. J Egypt Soc Parasitol. 2000;30:93-100.

3. Anding K, Gross P, Rost JM, Allgaier D, Jacobs E. The influence of uraemia and haemodialysis on neutrophil phagocytosis and antimicrobial killing. Nephrol Dial Transplant. 2003;18:2067-73.

4. Ando M, Gafvels M, Bergstrom J, Lindholm B, Lundkvist I. Uremic serum enhances scavenger receptor expression an activity in the human monocytic cell line U937. Kidney Int. 1997;51:785-92.

5. Ando M, Lundkvist I, Bergstrom J, Lindholm B. Enhance scavenger receptor expression in monocyte-macrophages in dialysis patients. Kidney Int. 1996;49:773-80.

6. Baiomy AM, Mohamed KA, Ghannam MA, Shahat SA, Al-Saadawy AS. Opportunistic parasitic infections among immunocompromised Egyptian patients. J Egypt Soc Parasitol. 2010;40:797-808.

7. Blastocystis hominis: commensal or pathogen? Lancet. 1991;337(8740):521-2.

8. Chieffi PP, Sens YAS, Paschoalotti MA, Miorin LA, Silva HGC, Jabur P. Infection by Cryptosporidium parvum in renal patients submitted to renal transplant or hemodialysis. Rev Soc Bras Med Trop. 1998;31:333-7.

9. Delves PJ, Roitt IM. The immune system: first of two parts. N Engl J Med. 2000;343:3749.

10. Ferreira MS. Infections by Protozoa in immunocompromised hosts. Mem Inst Oswaldo Cruz. 2000;95(Suppl 1):159-62.

11. Glorieux G, Vanholder R, Lameire N. Uraemic retention and apoptosis: what is the balance for the inflammatory status in uraemia? Eur J Clin Invest. 2003;33:631-4.

12. Henderson LW, Koch KM, Dinarello CA, Shaldon S. Hemodialysis hypotension: the interleukin hypothesis. Blood Purif. 1983;1:3-8.

13. Jager DJ, Grootendorst DC, Jager KJ, van Dijk PC, Tomas LMJ, Ansell D, et al Cardiovascular and noncardiovascular mortality among patients starting dialysis. JAMA. 2009;302:1782-9.

14. Janeway CA Jr, Medzhitov R. Innate immune recognition. Annu Rev Immunol. 2002;20:197-216.

15. Kain KC, Noble MA, Freeman HJ, Barteluk RL. Epidemiology and clinical features associated with Blastocystis hominis infection. Diagn Microbiol Infect Dis. 1987;8:235-44

16. K/DOQI. Clinical practice guidelines for chronic kidney disease: evaluation, classification and stratification. Am J Kidney Dis. 2002;39(Suppl 1):S11-266.

17. Kato S, Chmielewski M, Honda H, Pecoits-Filho R, Matsuo S, Yuzawa Y, et al. Aspects of immune dysfunction in end-stage renal disease. Clin J Am Soc Nephrol. 2008;3:152633.

18. Kimmel PL, Phillips TM, Simmens SJ, Peterson RA, Weihs KL, Alleyne S, et al. Immunologic function and survival in hemodialysis patients. Kidney Int. 1998;54:236 44 
GIL, F.F.; BARROS, M.J.; MACEDO, N.A.; JÚNIOR, C.G.E.; REDOAN, R.; BUSATTI, H.; GOMES, M.A. \& SANTOS, J.F.G. - Prevalence of intestinal parasitism and associated symptomatology among hemodialysis patients. Rev. Inst. Med. Trop. Sao Paulo, 55(2): 69-74, 2013.

19. Kulik RA, Falavigna DLM, Nishi L, Araújo SM. Blastocystis sp. and other intestinal parasites in hemodialysis patients. Braz. J Infect Dis. 2008;12:338-41.

20. Leelayoova S, Rangsin R, Taamasri P, Naaglor T, Thathaisong U, Mungthin M. Evidence of waterborne transmission of Blastocystis hominis. Am J Trop Med Hyg. 2004;70:65862.

21. Lim WH, Kireta S, Leedham E, Russ GR, Coates PT. Uremia impairs monocyte and monocyte-derived dendritic cell function in hemodialysis patients. Kidney Int. 2007;72:1138-48

22. Marques AB, Pereira DC, Ribeiro RCHM. Motivos e freqüência de internação dos pacientes com IRC em tratamento hemodialítico. Arq Ciênc Saúde. 2005;12:67-72.

23. Medzhitov R, Janeway C Jr. Innate immunity. N Engl J Med. 2000;343:338-44.

24. Minz M, Udgiri NK, Heer MK, Kashyap R, Malla N. Cryptosporidiasis in live related renal transplant recipients: a single center experience. Transplantation. 2004;77:1916-7.

25. Nazligul Y, Sabuncu T, Ozbilge H. Is there a predisposition to intestinal parasitosis in diabetic patients? Diabetes Care. 2001;24:1503-4.

26. Nimri LF, Batchoun R. Intestinal colonization of symptomatic and asymptomatic schoolchildren with Blastocystis hominis. J Clin Microbiol. 1994;32:2865-6.

27. Nimri LF. Evidence of an epidemic of Blastocystis hominis infections in preschool children in northern Jordan. J Clin Microbiol. 1993;31:2706-8.

28. Opatrny K Jr. Clinical importance of biocompatibility and its effect on haemodialysis treatment. Nephrol Dial Transplant. 2003;18(Suppl 5):41-4
29. Parkar U, Traub RJ, Kumar S, Mungthin M, Vitali S, Leelayoova S, et al. Direct characterization of Blastocystis from faeces by PCR and evidence of zoonotic potential. Parasitology. 2007;134:359-67.

30. Sarnak MJ, Jaber BL. Mortality caused by sepsis in patients with end-stage renal disease compared with the general population. Kidney Int. 2000;58:1758-64.

31. Sela S, Shurtz-Swirski R, Cohen-Mazor M, Mazor R, Chezar J, Shapiro G, et al. Primed peripheral polymorphonuclear leukocyte: a culprit underlying chronic low-grade inflammation and systemic oxidative stress in chronic kidney disease. J Am Soc Nephrol. 2005;16:2431-8

32. Seyrafian S, Pestehchian N, Kerdegari M, Yousefi HA, Bastani B. Prevalence rate of Cryptosporidium infection in hemodialysis patients in Iran. Hemodial Int. 2006;10:375-9.

33. Tan KSW. New insights on classification, identification, and clinical relevance of Blastocystis spp. Clin Microbiol Rev. 2008;21:639-65.

34. Turkcapar N, Kutlay S, Nergizoglu G, Atli T, Duman N. Prevalence of Cryptosporidium infection in hemodialysis patients. Nephron. 2002;90:344-6.

35. Wolfson M, Strong CJ, Minturn D, Gray DK, Kopple JD. Nutritional status and lymphocyte function in maintenance hemodialysis patients. Am J Clin Nutr. 1984;37:547-55

36. Young KH, Bullock SL, Melvim DM, Spruill CL. Ethyl acetate as a substitute for diethyl ether in the formalin-ether sedimentation technique. J Clin Microbiol. 1979;10:852-3.

Received: 28 December 2011

Accepted: 22 August 2012 